\title{
FAILURE OF LATCH MECHANISM FOR MOTION CONTROL OF SAFETY RODS (U)
}

by

W. W. F. Yau and D. R. Leader

Westinghouse Savannah River Company

Savannah River Site

Aiken, South Carolina 29808

The information contained in this document was prepared in connection with work done under Contract No. DE-AC09-89SR 18035 with the U.S. Department of Energy. By acceptance of this report, the publisher and/or recipient acknowledges the U.S. Government's right to retain a nonexclusive, royalty-free license in and to any copyright covering this report, along with the right to reproduce and to authorize others to reproduce all or part of the copyrighted report.

\section{MASTER}




\section{DISCLAIMER}

This report was prepared as an account of work sponsored by an agency of the United States Government. Neither the United States Government nor any agency thereof, nor any of their employees, makes any warranty, express or implied, or assumes any legal liability or responsibility for the accuracy, completeness, or usefulness of any information, apparatus, product, or process disclosed, or represents that its use would not infringe privately owned rights. Reference herein to any specific commercial product, process, or service by trade name, trademark, manufacturer, or otherwise does not necessarily constitute or imply its endorsement, recommendation, or favoring by the United States Government or any agency thereof. The views and opinions of authors expressed herein do not necessarily state or reflect those of the United States Government or any agency thereof.

This report has been reproduced directly from the best available copy.

Available to DOE and DOE contractors from the Office of Scientific and Technical Information, P.O. Box 62, Oak Ridge, TN 37831; prices available from (615) 576-8401, FTS 626-8401.

Available to the public from the National Techncial Information Service, U.S. Department of Commerce, 5285 Port Royal Rd., Springfield, VA 22161. 


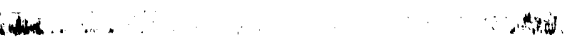

\title{
Oan s-arw thering \\ WESTINGHOUSE SAVANNAH RIVER COMPANY INTER-OFFICE MEMORANDUM
}

\author{
WSRC-RP-92-112 \\ Keywords: Latch Assembly, Impact Loading \\ Jaw Hanger Extension Buckling. \\ Safety Rod Vertical Motion \\ cc: L. M. Papouchado, 773-A \\ J. D. Spencer, 773-A

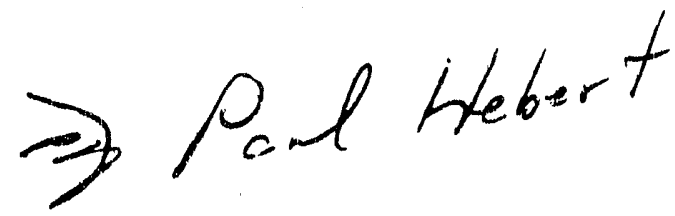 \\ T. L. Capeletti, 773.41 A \\ J. M. Norrison, 773-56A \\ S. K. Formby, 730 A \\ F. R. Utsch, 773- $\alpha$ \\ M. T. Ferencz, 723-9A \\ C. E. Sweeney, 723-A \\ SRL Records, 773-A (4) \\ January 16, 1992
}

TO. E. W. HOLTZSCHEITER, 773-A

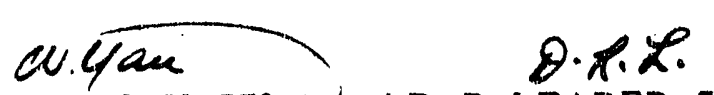

FROM W. W. F. YAU, 773-A and D. R. LEADER, 773-A

DOES NOT CONTAIN UNCLASSIFIED CONTROLLED

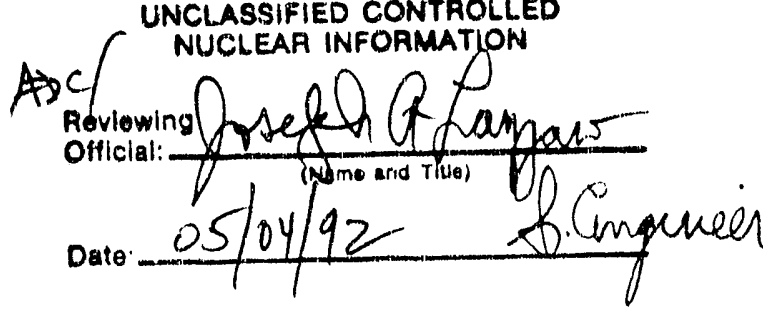

EAILURE OF LATCH MECHANISM FOR MOTION CONTROL OE SAEETY RODS- (U)

\section{Intreduction} UNCLASSIFIED

During safety rod tests in K-reactor prior to startup, one safety rod could not be lifted because the "button" (Figure 1) broke off and became lodged in the mechanism. Examination of the failed latch assembly along with other assemblies from both $\mathrm{K}$-Area and L-Area revealed several missing buttons as well as severely deformed "jaw hanger extensions". We participated in the investigation of the damage by request of the Reactor Restart Section. Based on our study of the latch mechanism, the modifications to the "safety rod extension", and the operating history of the machine, this memorandum describes the causes of the observed damage with experimental evidence and calculations io support the findings.

\section{Summary}

The original hemispherical top of the safety rod extension was removed to solve a delatching problem. The design modification caused difficulties to the latching operation in two respects: It reduces the accuracy of vertical alignment by destroying the

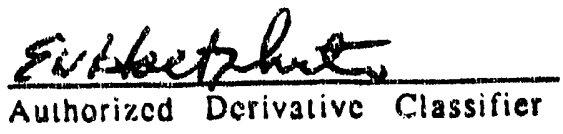


E. W. Holtzscheiter

WSRC-RP-92.112

Page 2

January 16,1992

centering capability of a spherical top, and because the safety rod extension is shortened, the vertical travel that is required for activating the latching mechanism without interference is virtually eliminated. For successful latching of a misaligned safely rod, manual forces were used often to push the tubular machine downward. Excessive forces of impact loading caused inelastic buckling of the jaw hanger extension. The contact surfaces between the 'ock plunger of the latch assembly and the top of the safety rod extension were not in parallel due to misalignment; the lower end of the lock plunger, or the button, fell off as a result of excessive bending stress at impact. The intensity of the impact force was equivalent to static load of 3000 pounds. The safety rod snubber can resist a force of 4600 pounds withour inelastic deformation (Reference 1). A new design for increased alignment capability and latching clearance is in progress.

\section{Discussien}

Figure I shows the components of the latch assembly and a latching sequence with no alignment problems. It is noticed that the downward motion of the jaw hanger causes the locking balls fall into positions to activate the radial motion of the jaws. The vertical distance traveled by the locking balls, $d_{1}$, is virtually the same as the clearance between the lower tip of the jaw hanger extension and the top of the safety rod extension at the beginning of the sequence, $d_{2}$. The length of a buckled jaw hanger extension was found shortened by 0.14 inch.

The jaw hanger extension is a hollow cylinder with four vertical slots (Figure 2) for access windows of the jaws. Compression tests (Reference 2) indicated a buckling load greater than 2000 pounds. Inelastic buckling became pronounced at loads greater than 3000 pounds.

Calculation for the critical force at the onset of inelastic buckling is based on the thinnest section of the jaw hanger extension. The cross-section for each of the four ligaments between slots and its design dimensions are shown in Figure 2. The critical force, P. satisfies the following buckling equation (Reference 3 )

$$
\sigma_{y}=\frac{P}{A}\left[1+\frac{x_{0} x_{1}}{r_{0}^{2}} \sec \left(\frac{l}{2 r_{0}} \sqrt{\frac{P}{A E}}\right)\right]
$$

where $\sigma_{y}=170 \mathrm{ksi}$, is the yield strength of stainless steel ARMCO 17.4PH with $1025^{\circ} \mathrm{F}$ heat treatment, $E=30(10)^{6} \mathrm{psi}$ is the modulus of elasticity, $A=0.0127 \mathrm{in}^{2}$ is the crosssectional area, $x_{0}=0.3382 \mathrm{in}$. is the load eccentricity, $x_{1}=0.0376 \mathrm{in}$. is the distance from the location of maximum compression to the neutral axis, $r_{0}=0.0620 \mathrm{in}$. is the radius of gyration, and $1=1.422 \mathrm{in}$. is the length of the thin section. Formulas used for computation of these quantities are 
E. W. Holtzscheiter

WSRC-RP-92-112

Page 3

January 16,1992

$$
\begin{aligned}
& \lambda_{a}=\sin ^{-1} \frac{c}{a} \\
& \lambda_{b}=\sin ^{-1} \frac{c}{b} \\
& A=\frac{\pi}{4}\left(a^{2}-b^{2}\right)-a^{2} \lambda_{a}+b^{2} \lambda_{b}-c^{2}\left(\cot \lambda_{a}-\cot \lambda_{b}\right) \\
& M=\frac{1}{3} \sqrt{2}\left[a^{3} \cos ^{3} \lambda_{a}-b^{3} \cos ^{3} \lambda_{b}-\frac{3}{2} c\left(a^{2}-b^{2}\right)\right] \\
& \left.I^{\prime}=\frac{\pi+2}{16}\left(a^{4}-b^{4}\right)-\frac{1}{4} \operatorname{ca}^{4} \lambda_{a}-b^{4} \lambda_{b}\right)-\frac{1}{2} c^{2}\left(a^{2}-b^{2}\right) \\
& x_{0}=\frac{M}{A} \\
& x_{1}=x_{0}-b \sin ^{4}\left(\frac{\pi}{4}-\lambda_{b}\right) \\
& I=I^{\prime}-A x_{0}^{2} \\
& r_{0}=\left(\cot ^{3} \lambda_{a}-\cot ^{3} \lambda_{b}+\cot \lambda_{a}-\cot \lambda_{b}\right)
\end{aligned}
$$

where $a=0.372$ in. and $b=0.310$ in. are the outside and inside radii of the cylinder respectively; $c=0.159$ in the half-width of the slots.

Solution to the buckling equation gives $P=470$ pounds, so the minimum buckling load is

$$
F_{\min }=4 P=1880 \text { pounds }
$$

because there are four ligaments. There should be no permanent deformation for the jaw hanger extension, when the minimum buckling load is applied. Consistent with the static test results, a realistic buckling load is about 3000 pounds, and the plastic deformation of 0.14 inch is mostly produced by Inads greater than $F_{\min }$; hence

$$
W=1 / 2(0.14)\left(3000+F_{\min }\right)=210 \text { in }-1 b
$$

is the energy required for inelastic buckling.

The weight of the latch assembly is estimated at 50 pounds. Assuming that the operator lifted the assembly by 18 inches and released it by free fall, the energy available for impact is 900 in-1b, which is more than 4 tirnes of the required. Efficiency of the work done for such impact loading depends on the particular situation involving misalignment and resistances of associated components, precise determination of the balance of energy is difficult and considered as unwarranted. 
E. W. Holtzscheiter WSRC-RP-92-112

Page 4

January 16, 1992

\section{References}

1. WSRC-RP-91-677, Structural Response of Safety Rods to Impace Loading, June 19, 1991.

2. Fabrication Laboratory Work Request \#50, January 8, 1992.

3. Timoshenko, S. and Young, D. H., "Strength of Materials" p. 283, 4th edition, Nostrand, N. Y. 1962.

WWFY/tyb 


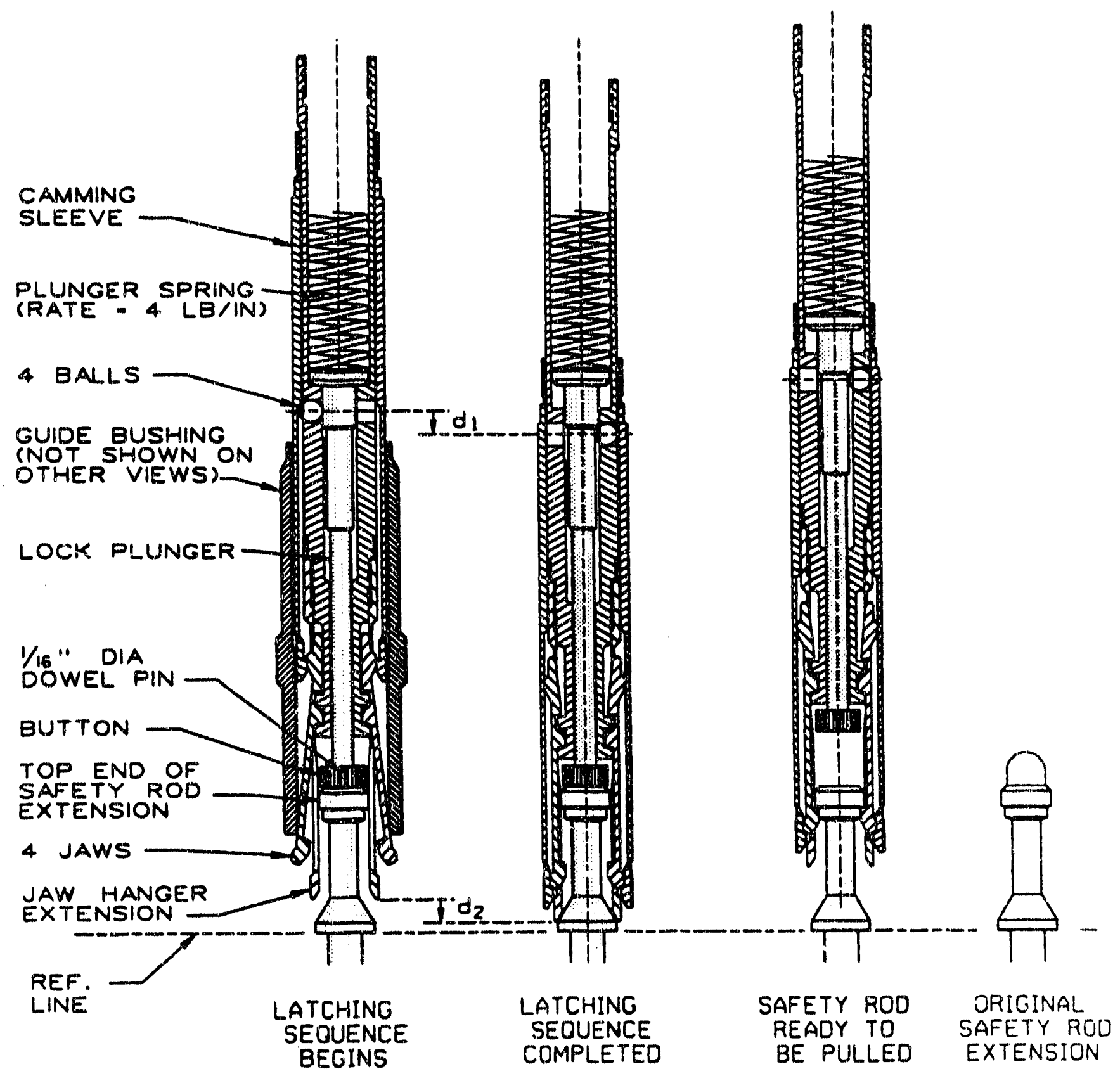

FIGURE 1. SAFETY ROD LATCH ASSEMBLY 

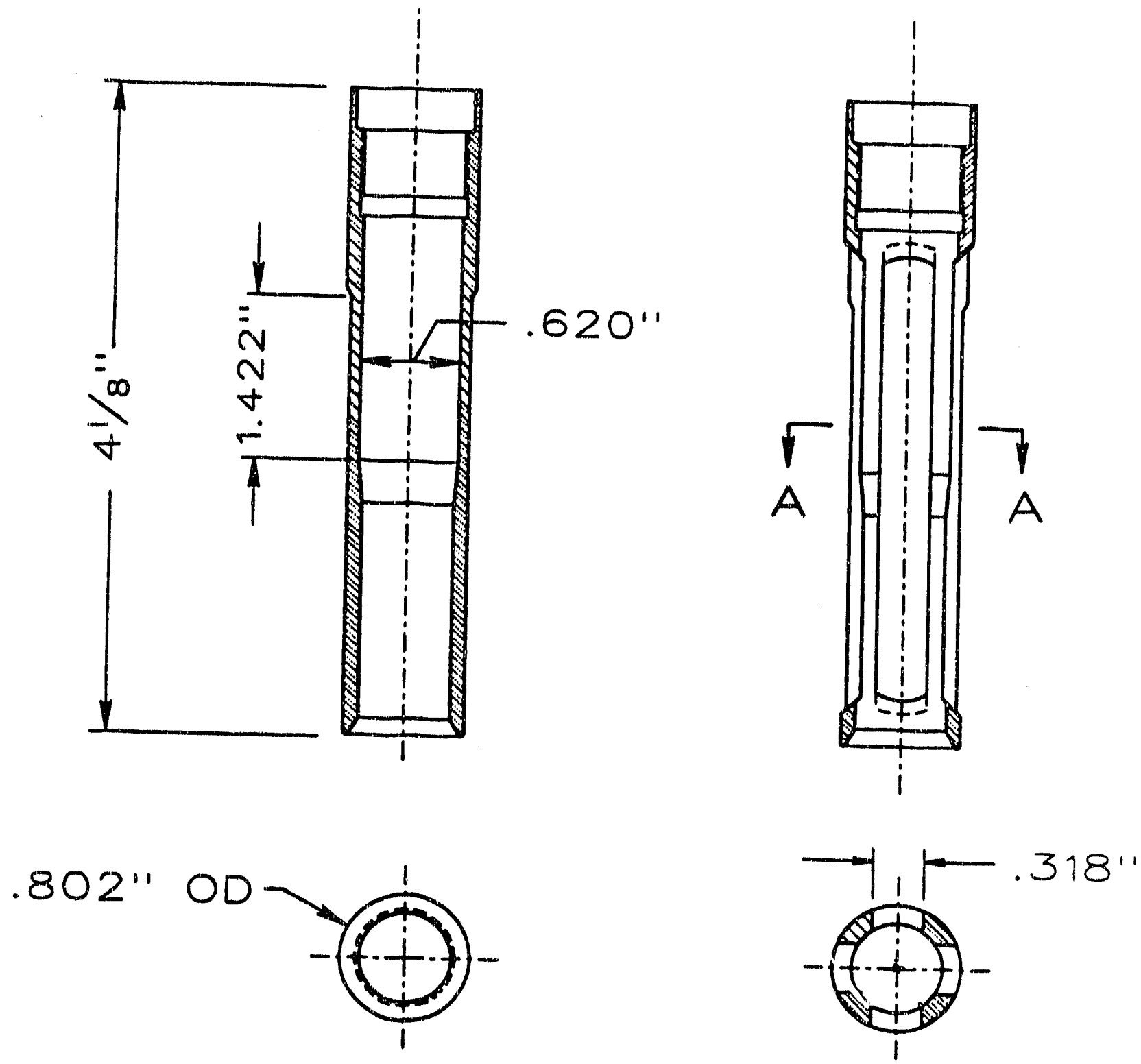

SECTION A - A

FIGURE 2. JAW HANGER EXTENSION 


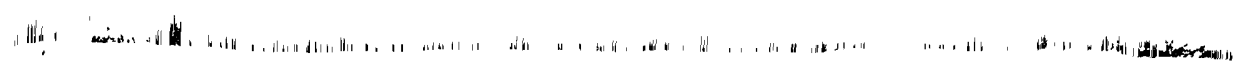

d.
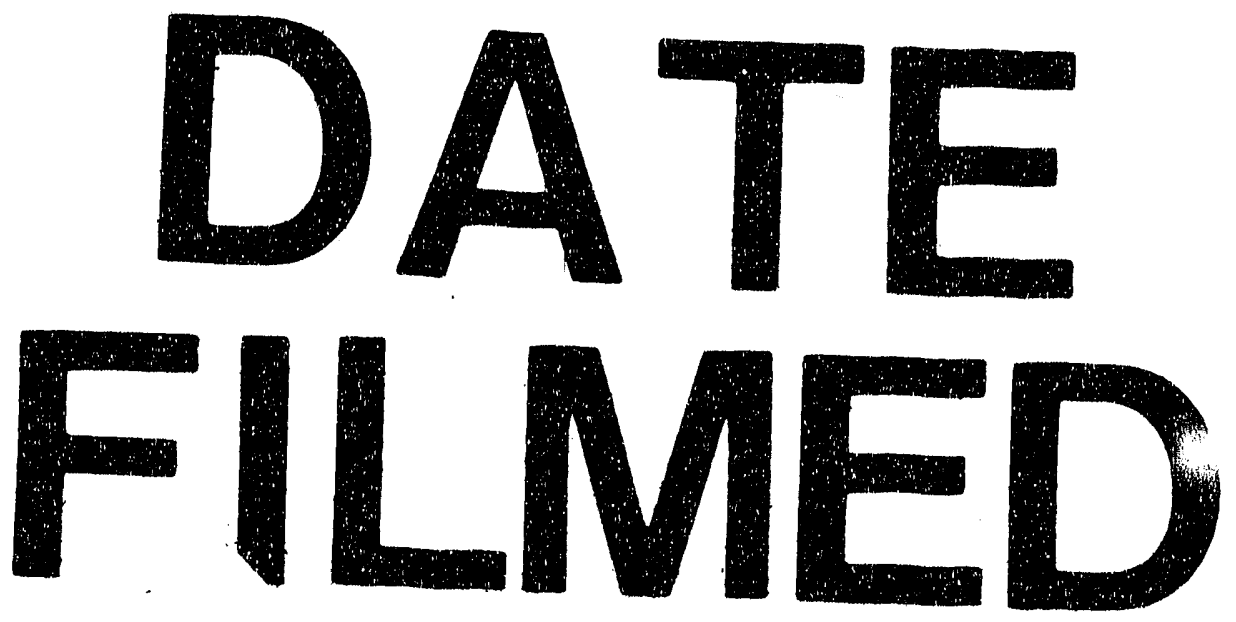

㠃

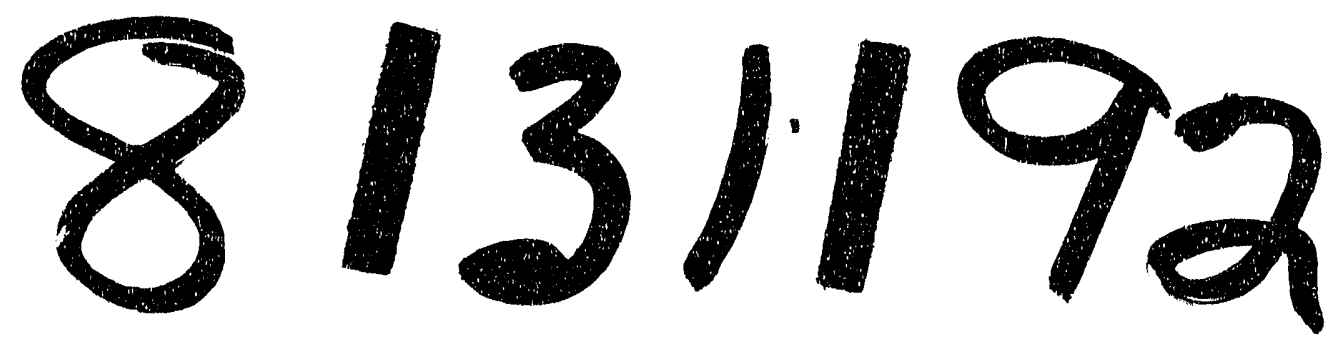




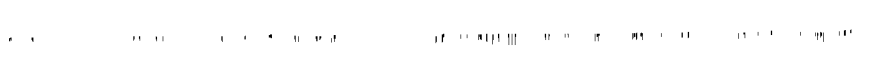

